The ability of selected filter materials in removing nutrients, metals, and microplastics from stormwater in biofilter structures

Kuoppamäki, Kirsi

2021-03

Kuoppamäki , K, Pflugmacher Lima , S , Scopetani , C \& Setala , H 2021 , ' The ability of selected filter materials in removing nutrients, metals, and microplastics from stormwater in biofilter structures ' , Journal of Environmental Quality , vol. 50 , no. 2 , pp. 465-475 . https://doi.org/10.1002/jeq2.202

http://hdl.handle.net/10138/339030

https://doi.org/10.1002/jeq2.20201

acceptedVersion

Downloaded from Helda, University of Helsinki institutional repository.

This is an electronic reprint of the original article.

This reprint may differ from the original in pagination and typographic detail.

Please cite the original version. 
Publisher: AGRONOMY; Journal: AGROJNL:Agronomy Journal; Copyright: Will notify...

Volume: Will notify...; Issue: Will notify...; Manuscript: aj-2017-08-0123-a; DOI: ; PII: <txtPII>

TOC Head: ; Section Head: ; Article Type: ARTICLE

\title{
The Ability of Selected Filter Materials in Removing Nutrients, Metals and Microplastics from Stormwater in Biofilter Structures
}

Kirsi Kuoppamäki, Stephan Pflugmacher Lima, Costanza Scopetani, and Heikki Setälä

K. Kuoppamäki, S. Pflugmacher Lima, C. Scopetani, and H. Setälä, Faculty of Biological and Environmental Sciences, Ecosystems and Environment Research Programme, University of Helsinki, Niemenkatu 73, FIN-15140 Lahti, Finland

S. Pflugmacher Lima, Korean Institute of Science and Technology, KIST-Europe, Joint Laboratory of Applied Ecotoxicology, Campus E7 1, 66123 Saarbrücken, Germany

S. Pflugmacher Lima, University of Manitoba, Clayton H. Riddell Faculty of Environment, Earth \& Resources, Department of Environment and Geography, Wallace Building, 125 Dysart Road, Winnipeg, MB, Canada R3T 2N2

\begin{abstract}
Creative solutions to manage stormwater include ecologically based designs, such as biofilter structures. A laboratory experiment was established to study the ability of biofilters to

This article has been accepted for publication and undergone full peer review but has not been through the copyediting, typesetting, pagination and proofreading process, which may lead to differences between this version and the Version of Record. Please cite this article as doi: $10.1002 /$ jeq2.20201.
\end{abstract}

This article is protected by copyright. All rights reserved.

Page 1 of 30 
remove nutrients, metals, total suspended solids (TSS) and total organic carbon originating from roadside stormwater as melted snow. Special attention was paid on the removal of phosphorus (P). In addition, the fate of microplastics (MPs) in the biofilters was followed. The materials selected for biofilters were crushed light-expanded clay aggregates without biochar or amended with biochar, Filtralite $P ®$ clay aggregates, crushed concrete or filter sand. A layer to support grass growth was placed above these materials. Stormwater was rich in TSS with associated P, and metals, which were substantially retained by all biofilters.Filtralite and concrete had almost $100 \% \mathrm{P}$ removal, but the high $\mathrm{pH}$ had adverse effects on plants. Light-expanded clay aggregates had lower retention of $\mathrm{P}$ andwhen mixed with biochar $(30 \% \mathrm{v} / \mathrm{v})$, the leaching of $\mathrm{P}$ increased, while nitrogen retention was improved but . None of the materials was ideal for treating both nutrients and metals, but sand was generally best. Vegetation improved nitrogen retention and stormwater infiltration. Plant roots formed preferential pathways for water and associated substances, evidenced by the accumulation of MPs along root channels. No MPs were found in discharge. Given the high loading of suspended solids and associated contaminants in snow-melt from traffic areas and their efficient retention in biofiltration, results of this study suggest the implementation of such stormwater management solutions along road verges.

\section{INTRODUCTION}

Urban areas are significant sources of pollution and, being located mostly next to water bodies, contribute to the degradation of aquatic ecosystems (Grimm et al., 2008; Göbel et al, 2007). Thus, ecologically based designs for stormwater capture are becoming more common as creative solutions to manage urban runoff and regulate biogeochemical cycles (Eckhart et al., 2017; Grimm et al., 2008). The amount of contaminants in urban runoff correlates 
strongly with the degree of impervious surfaces and traffic intensity (Charters et al., 2016; Ellis and Mitchell, 2006; Kuoppamäki et al., 2014; Valtanen et al., 2014). Vehicular-derived inputs of sediment, nutrients and metals are the main contributors to urban pollution (Charters et al., 2016; Ellis and Mitchell, 2006). Particles and pollutants bound in them, including phosphorus (P), metals and PAHs, are readily deposited close to road verges (Kuoppamäki et al., 2014; Westerlund and Viklander, 2006) and can be captured by biofiltration (Flanagan et al., 2019; Hatt et al., 2009). Dissolved nutrients and metals are less well retained by biofilters (Flanagan et al., 2019; Hatt et al., 2009; Valtanen et al., 2014) but can be enhanced by, e.g. amending soils with biochar (Kuoppamäki et al., 2019).

Recently, microplastics (MPs), i.e. plastic items smaller than $5 \mathrm{~mm}$ (EPA, 2011), have received attention among the scientific community and publicity for being ubiquitous and increasingly found in the environment worldwide (Ajith et al., 2020). MPs can act as a vector of contaminants that may bioaccumulate in organisms that ingest plastic debris by mistake (Scopetani et al., 2018). Traffic, e.g. tire abrasion, is one of the main sources of MPs (Kole et al., 2017) making cities major contributors of MP pollution. Given the good retention of particles by biofiltration, also microplastics originating from urban milieus may be captured and, thus, prevented from entering adjacent aquatic systems.

Engineered components in biofilters are essential to retain elements in stormwater and must be understood to avoid possible unwanted consequences, such as the leaching of nutrients or metals from the filter media itself (Blecken et al., 2010; Hatt et al., 2009). Limited knowledge on how to construct viable biofiltration structures is one of the greatest barriers to a wider adoption of new stormwater management techniques (Eckhart et al., 2017). Bioretention media typically contain sand (Eckhart et al., 2017), but in order to support sustainable, low impact development and circular economy, there is a need to explore 
different types of media, including reused products, such as industrial by-products (Funai and Kupec, 2017). Alternatives to sand should preferably have a low environmental footprint. Besides being recycled, they should be local rather than faraway imported materials (Hatt et al., 2009; Mohanty et al., 2018). Filter materials should also be able to support plant growth, since by taking up nutrients, especially nitrogen, and improving hydraulic conductivity, vegetation is an essential component of biofilters (Funai and Kupec, 2017; Hatt et al., 2009; Henderson et al., 2007; Kuoppamäki et al., 2019; Leroy et al., 2016; Valtanen et al., 2017).

When attempting to reduce eutrophication of fresh waters, a prerequisite is to decrease the loading of $\mathrm{P}$, the key nutrient stormwater treatment systems are intended to remove (Funai and Kupec, 2017). This can be enhanced by using filter materials with high P retention capacity, such as calcinated expanded clay, limestone (Vohla et al., 2011) or aerated concrete (Karczmarczyk et al., 2014). Concrete aggregates are a cheap residue to be considered in biofiltration (Egemose et al., 2012). Light-expanded clay aggregates also retain P (Amado et al., 2012; Vohla et al., 2011) but, being non-recyclable material, is less environmentally sustainable than e.g. concrete residues. However, replacing sand with lightweight expanded shale (clay) is desirable since shale has the good physical properties of sand and the biological and chemical benefits of clay (Funai and Kupekc, 2017). Biochar, when produced from waste or by-products, meets the criteria for being recycled and can retain nutrients and/or metals, depending on feedstock material and production process (Kuoppamäki et al. 2019; Mohanty et al., 2018; Shaheen et al., 2018).

To enhance our understanding on the performance of filtration materials in stormwater biofiltration, a laboratory experiment was established to compare the retention of suspended solids, nutrients, metals and total organic carbon by five types of filter materials for stormwater management suggested by product developers and practitioners as a a part of a 
project aiming to improve the sustainable treatment of urban runoff. Filtralite $\mathrm{P} \AA$, a lightexpanded clay aggregate product developed for removing P from water, was hypothesized to be most efficient in removing $\mathrm{P}$, followed by normal crushed light-expanded clay aggregates and, furthermore, concrete was assumed to be a competent alternative recycled material. Enhanced nutrient retention was expected in light-expanded clay aggregates amended with biochar. Sand was selected as a control due to its widespread use as a filter material and was assumed to be less efficient in the removal of pollutants, especially $\mathrm{P}$, as compared to materials developed for this purpose. Attention was paid to the suitability of the materials to support plant growth. The retention of MPs, i.e. fluorescent polyethylene microspheres (up to $10 \mu \mathrm{m}$ in diameter), was studied in biofilters containing either sand or normal light-expanded clay aggregates.

\section{MATERIALS AND METHODS}

\section{Experimental setup}

A replicated laboratory experiment was established to simulate biofiltration systems receiving urban runoff from roads with heavy traffic and the deposition of MPs. Five different materials were studied for their capability to purify stormwater, each in five vegetated and one non-vegetated treatments. The materials selected for the experiment were: 1) crushed light-expanded clay aggregates (hereafter referred to as L) sieved to $3-8 \mathrm{~mm}, 2$ ) the same L amended ( $30 \%$ by volume) with biochar made of spruce wood (hereafter referred to "Lbc"), 3) 0.5-4.0 mm L activated to retain P (Filtralite $\mathrm{P}^{\circledR}$; hereafter "Fil"), 4) crushed 2$20 \mathrm{~mm}$ recycled concrete, a side product of a concrete factory (hereafter "Con") and 5) 0.5-2 $\mathrm{mm}$ filter sand (hereafter "S"). Biochar was produced from spruce under slow pyrolysis at $600^{\circ} \mathrm{C}$ and had a weight of $167 \mathrm{~g} \mathrm{~L}^{-1}, \mathrm{pH} 8.9$, BET surface area of $163 \mathrm{~m}^{2} \mathrm{~g}^{-1}$ and a pore size 
distribution of $95 \%<2 \mathrm{~nm}$ and $5 \% 2-50 \mathrm{~nm}$. Biochar was sieved through $2 \mathrm{~mm}$ to remove fines, resulting in 2-20 $\mathrm{mm}$ particle size.

Each treatment had six replicates of which five had plants, reed canary grass Phalaris arundinacea variegatus, and one was without plants. This species was selected due to its good performance in stormwater biofiltration (Valtanen et al. 2017). One planted replicate of each treatment was placed in a transparent acrylic container that allowed for the monitoring of root growth and the fate of MPs. All the remaining replicates were placed in PVC containers (height $60 \mathrm{~cm}$ and diameter $16 \mathrm{~cm}, 0.1 \mathrm{~m}^{3}$ volume) the size of containers being comparable to several previous studies on stormwater biofiltration (e.g. Barrett et al., 2013; Feng et al., 2012; Glaister et al., 2014) and suitable for the space available for this study. The experiment altogether consisted of 30 cylindrical containers, . Each container was equipped with a $50 \mathrm{~cm}$ transparent riser pipe, attached to the outlet on the lower edge. This pipe was used to monitor and control water level in the containers and to collect water samples. The containers were placed in a randomised block design below plant lights $(240-370 \mu \mathrm{mol}$ photos $\mathrm{m}^{-2} \mathrm{~s}^{-1}$ ) with a light:dark cycle of 14:10 h. At the bottom of each container, a $5 \mathrm{~cm}$ layer of coarse gravel (diameter $c a .20 \mathrm{~mm}$ ) was added as a drainage layer and the filter material was added above this as a $35 \mathrm{~cm}$ layer. At the top of each container, a $10 \mathrm{~cm}$ thick layer of peat and filter sand mixture was added as the growing medium for plants, also in the containers without plants.

\section{Infiltration of stormwater and microplastics}

Stormwater was collected as snow just before melting in early April 2018 at crossroads in the city of Lahti, southern Finland, next to a busy road (ca. 34000 vehicles/day), where roadside snow is shown to be rich in contaminants (Kuoppamäki et al., 2014). Snow was kept in cold storage until using it as melted water for irrigating the biofilters. 
Before stormwater addition, containers were allowed to stabilise and the plants to grow for 7 weeks at $18{ }^{\circ} \mathrm{C}$, and biofilters were kept moist by irrigating them weekly with $250 \mathrm{ml}$ tap water. Two rain events were designed to mimic minor rainfall depth of $<10 \mathrm{~mm}$, typical for the local climate, with daily precipitation exceeding this depth is recorded on only 10 to 15 days yearly (FMI 2020). The first irrigation simulated a "spring event" with $4.5 \mathrm{~mm}(=1.8$ 1/container) stormwater entering wet soil after snowmelt. Thereafter, temperature was raised to $23{ }^{\circ} \mathrm{C}$ and biofilters were left without watering for two weeks until the second irrigation, simulating a "summer event" with $6 \mathrm{~mm}(=2.4$ 1/container $)$ runoff on dry soil.

To ensure that discharge originated from the added stormwater, containers were drained before both irrigations. Stormwater was left infiltrating for 24 hours and then discharge was collected, volume quantified and samples taken for water quality analyses.

Twelve weeks after the start of the experiment, $18^{\text {th }}$ June, S and light-expanded clay treatments were used for a microplastic infiltration experiment. $5 \mathrm{~g}$ fluorescent polyethylene microplastic beads up to $10 \mu \mathrm{m}$ in diameter, coated with luminescence dye (manufacturer Shenyang LTD, Shenyang 110000, Liaoning province, PR China) was mixed in $250 \mathrm{ml}$ tap water and added to each container. The fate of microplastic granules was visually followed during the last 5 weeks of the experiment through the walls of the transparent acrylic containers and, at the end of the experiment, the deepest depth with the presence of MPs was examined in all 12 containers used in the MPs study.

Grasses were cut at $25 \mathrm{~cm}$ height after the second stormwater infiltration and at the end of the experiment on $26^{\text {th }}$ July, all plant material was carefully collected. Shoots and roots were dried at $60{ }^{\circ} \mathrm{C}$ for $20 \mathrm{~h}$ and weighed for dry mass. The total length of 17 weeks was considered enough for the experiment, given the declining condition of grasses in Fil and Con 
treatments. In addition, the experiment was a part of a larger project, which was approaching its end.

\section{Laboratory analyses}

Samples from discharge, i.e. infiltrated stormwater, and a composite sample for stormwater used for irrigation were first measured for $\mathrm{pH}$ by using WTW Inolab pH 720.

Total suspended solids (TSS) were analysed according to the SFS-EN 872 (2005) standard by filtering a known volume of water $(100-900 \mathrm{ml})$ through pre-weighed Whatman GF/C filters (1.2 $\mu \mathrm{m}$ pore size; Whatman International, Maidstone, UK), which were dried at $105{ }^{\circ} \mathrm{C}$ for 2 $\mathrm{h}$ and weighed again to obtain the concentrations of TSS as $\mathrm{mg}^{-1}$. Total organic carbon (TOC) was analyzed from samples taken after the first irrigation according to SFS-EN 1484 by using Teledyne-Tekmar Apollo 9000HS with 1-100 ppm C range. Nonfiltered samples were oxidized and analyzed for concentrations of total nitrogen (TN) according to SFS-EN ISO 11905-1 and total phosphorus (TP) according to ISO/DIS 15681-2 standard; which was also used for analyzing dissolved $\mathrm{P}$ as phosphate $\left(\mathrm{PO}_{4}\right)$. Filtered samples were oxidized and measured for total dissolved $\mathrm{P}$ also in particles that penetrate through $0.45 \mu \mathrm{m}$ filter

(Whatman). Dissolved nitrogen $\left(\mathrm{NO}_{\mathrm{x}}\right.$; including $\mathrm{NO}_{2}$ and $\left.\mathrm{NO}_{3}\right)$ was analyzed following the SFS-EN ISO 13395 standard. All nutrient fractions were analyzed using a spectrophotometer (Gallery Plus, Thermo Scientific).

Concentrated $\mathrm{HNO}_{3}(50 \mu \mathrm{l})$ and $50 \mu \mathrm{l}$ of a $1 \mathrm{mg} \mathrm{L}^{-1}$ indium solution was added as an internal standard for metal analyses and the sample was mixed well with vortex. For dissolved metals, samples were filtered through $0.45 \mu \mathrm{m}$ filter and for total metals (both particle-bound and dissolved), a $20 \mathrm{ml}$ sample of non-filtered water was digested with $5 \mathrm{ml}$ of concentrated nitric acid and $25 \mathrm{ml}$ of ultrapure water in a Mars 6 microwave device (method US EPA 3015a). One $\mathrm{ml}$ of the sample was diluted with $4 \mathrm{ml}$ of ultrapure water and $50 \mu \mathrm{l}$ of 
indium $\left(1 \mathrm{mg} \mathrm{l}^{-1}\right)$ was added to the sample. Metal concentrations were determined using a Perkin-Elmer Elan 6000 ICP-MS according to SFS-EN ISO 17294-2 (2005).

The leaching of metals and nutrients from crushed light-expanded aggregates, biochar, Filtralite $\mathrm{P}^{\circledR}$, crushed concrete and sand was tested by applying SFS-EN 13652 standard. $20 \mathrm{~g}$ of each material was weighed to $100 \mathrm{ml}$ ultrapure water, kept in a shaker for $60 \mathrm{~min}$, after which subsamples were taken for analyses as described above.

\section{Data analyses}

Statistical analyses were run using IBM SPSS Statistics Version 21 for Windows. The impact of filter treatments on water retention and discharge quality was studied by repeated ANOVA together with Tukey's post hoc test to detect possible differences between the treatments at $<0.05$ significance level. If the assumptions for parametric tests were not met, log-transformation was used to stabilize heterogeneous variances or to normalize the distribution (nevertheless, non-transformed values appear in the figures). The same analysis was used to study the impact of filter treatments on plant biomass. Independent samples Ttest was employed to study the impacts of vegetation on discharge quality and water retention by comparing values obtained from non-vegetated treatments with averages of the vegetated treatments.

In order to study how well each material retains multiple metals, original EMC values

$\left(x_{i}\right)$ were normalized by calculating z-scores $\left(z_{i}\right)$ :

$z_{i}=\left(x_{i}-m\right) / s$, where $m=$ mean and $s=$ standard deviation

As z-cores are standardized values, they enable a comparison between different variables irrespective of their absolute values and can be summed to compare the amount of 
metal mixtures in the discharge from the various bioretention treatments. The impact of filter treatments on these z-scores was analyzed by repeated ANOVA as described above.

\section{RESULTS}

\section{The retention of nutrients in biofilters}

The added stormwater was rich in total phosphorus (TP), while event mean concentrations (EMC) in discharge from biofilters were very low (Fig. 1). Fil retained all TP and the second best filters were Con and S (Tables 1 and 2, Fig. 1). Only ca. $0.30 \%$ and $0.15 \%$ of stormwater P was dissolved TP and phosphate $\left(\mathrm{PO}_{4}\right)$, respectively. Dissolved TP in stormwater was very low compared to biofilter outputs, resulting in mostly negative retention (Table 1). $\mathrm{PO}_{4}$ was reduced by Fil, Con and, in the latter irrigation, $\mathrm{S}$, but increased in concentration in the discharge of $\mathrm{L}$ and $\mathrm{Lb}$ (Table 1, Fig. 1).

Lb, Fil and S had 11-37\% total nitrogen (TN) removal in the second irrigation, but otherwise more $\mathrm{TN}$ was present in outlet than input water (Table 1, Fig. 1). $\mathrm{NO}_{\mathrm{x}}$ retention was highest in $\mathrm{Lb}$ and $\mathrm{S}$ (Table 2) and was improved by vegetation $(\mathrm{t}=2.49, p=0.038$; Fig. 1).

Discharge from biofilters following stormwater irrigations had lower concentrations of $\mathrm{PO}_{4}$ and $\mathrm{NO}_{\mathrm{x}}$ (Fig. 1) compared to those obtained in the leaching test, which suggested that light-expanded clay aggregates and biochar were sources of $\mathrm{PO}_{4}$, and concrete a source of NOx (Table A1).

\section{The retention of metals in biofilters}

The added stormwater had high concentrations of total metals: zinc ( $\mathrm{Zn}) 1222 \mu \mathrm{g} \mathrm{L}{ }^{-1}$, cobalt (Co) $136 \mu \mathrm{g} \mathrm{L}^{-1}$, cadmium (Cd) $1 \mu \mathrm{g} \mathrm{L}^{-1}$, arsenic (As) $21 \mu \mathrm{g} \mathrm{L}^{-1}$, copper (Cu) $639 \mu \mathrm{g} \mathrm{L}^{-1}$, 
chromium (Cr) $250 \mu \mathrm{g} \mathrm{L}^{-1}$, lead $(\mathrm{Pb}) 44 \mu \mathrm{g} \mathrm{L} \mathrm{L}^{-1}$ and nickel (Ni) $133 \mu \mathrm{g} \mathrm{L} \mathrm{L}^{-1}$. However, concentrations in biofilter discharge were mostly below the limits of quantification, except for As, the concentrations of which were $2 \times$ higher in discharge from $\mathrm{L}$ and $\mathrm{Lb}(\mathrm{ca} .40 \mu \mathrm{g} / \mathrm{l})$ than in stormwater, and significantly higher compared to the other treatments (Table 2). $\mathrm{Cu}$ was most efficiently retained by Fil and Ni by S and Con (Table 2).

Dissolved metals in stormwater were only between $<1 \%$ and $3 \%$ of total metal levels, but elevated levels were measured in the discharge (Fig. 2). Discharge from L and Lb had the highest concentrations of $\mathrm{Cd}$ and As. Fil was associated with elevated $\mathrm{Pb}$ levels. Discharge from $\mathrm{Con}$ had the highest levels of $\mathrm{Cr}$ and $\mathrm{Pb}$. $\mathrm{Zn}$ was reduced by biochar (Table 2, Fig. 2). However, the leaching of dissolved metals from the filter materials to ultrapure water was low, below maximum limits considered suitable for landfill and tap water in Finland. Only As leached from $L$ at levels exceeding the maximum limit suitable for tap water (Table A1). To evaluate the ability of the materials to retain a mixture of dissolved metals, standardized EMC values were compared. $\mathrm{S}$ turned out to be the best filter material (Anova; $F=10.97, p$ $<0.001$, Tukey $p<0.01$; Fig. 2). Vegetation did not affect retention of the metal mixture.

\section{The retention of particles and microplastics (MPs) in biofilters}

96-100\% of total suspended solids (TSS) were retained by the biofilters (Table 1) despite high concentrations of TSS in the stormwater (7796 and $7027 \mathrm{mg} \mathrm{L}^{-1}$ in the first and second irrigation event, respectively). TSS concentrations in biofilter discharge varied from $c a$. 10 to $60 \mathrm{mg} \mathrm{L}^{-1}$.

The infiltration of MPs was seen via fluorescent color in darkness and primarily present especially around plant roots (Fig. 3). By the end of the experiment, the maximum 
infiltration depth of the MP beads in vegetated systems was $8-12 \mathrm{~cm}$, while in non-vegetated ones it was 4-6 cm. No MPs were detected in the discharge.

\section{pH in stormwater and discharge from biofilters, and the retention of TOC in biofilters}

Stormwater had a pH 7.9 and when infiltrating through Fil and Con became highly alkaline having a $\mathrm{pH}$ value greater than 12 , which was significantly higher as compared to discharge from the other biofilters with $\mathrm{pH}$ 7-8 (Table 2).

Stormwater contained $35 \mathrm{mg} \mathrm{L}^{-1}$ TOC, which was retained only by Fil and S (Table 1), with average concentrations of 14 and $33 \mathrm{mg} / \mathrm{l}$, respectively. $\mathrm{L}$ and $\mathrm{Lb}$ had $2 \mathrm{x}$ higher concentrations compared to stormwater. Discharge from Con contained ca. $113 \mathrm{mg} \mathrm{L}^{-1} \mathrm{TOC}$.

\section{The volumetric retention of stormwater in biofilters}

$20-40 \%$ of the added stormwater was retained, with the highest retention in F and the lowest in $\mathrm{S}$ (Tables 1 and 2). The presence of vegetation improved retention during the summer event by $c a .20 \%$ as compared to non-vegetated treatments $(\mathrm{t}=-4.83 p=0.001)$. Plants accelerated water infiltration, as it only took minutes to absorb the added stormwater, while in non-vegetated containers it took several hours.

\section{Plant growth in biofilters}

In $\mathrm{L}, \mathrm{Lb}$ and $\mathrm{S}$, grass roots reached the bottom of the containers $(50 \mathrm{~cm}$ from the soil surface) by the end of the first month. However, roots did not extend deeper than $15 \mathrm{~cm}$ from the soil surface in Fil and Con. The weakened growth of roots was associated with stunted growth evidenced as lower root biomass $(6.2 \pm 0.7$ and $5.6 \pm 0.7 \mathrm{~g} \mathrm{dw}$ in Fil and Con, respectively) 
compared to the other treatments $(10.1 \pm 2.6,8.0 \pm 0.8$ and $10.9 \pm 1.9 \mathrm{~g} \mathrm{dw}$ in $\mathrm{L}, \mathrm{Lb}$ and $\mathrm{S}$, respectively).

\section{DISCUSSION}

\section{Nutrients and total suspended solids}

Particles in the melted roadside snow were very abundant, the TSS concentration being $1.5 \mathrm{x}$ higher than found by Valtanen et al. (2014) in wintertime urban runoff. Antiskid treatment and the wearing of road surfaces by winter tires next to the snow collection site probably were the main origins of TSS. Stormwater was also enriched with TP, which was almost entirely bound to particles, as is typical to urban runoff ( $c f$. Blecken et al., 2010). Given the good retention of TSS (97-100\%), TP was also well retained by biofilters. TSS and associated TP is removed simply by effective physical straining in biofiltration (Glaister et al., 2014; Hatt et al., 2007; Mangangka et al., 2015; Shrestha et al., 2018). As expected, the most efficient filter material in the removal of TP was Filtralite $\mathrm{P}^{\circledR}$ (Fil) with a $99-100 \%$ reduction, while crushed concrete (Con) turned out to be a competent alternative recycled material with $87-98 \%$ removal. Traditional filter sand (S) was also efficient (95-97\%). The good performance of biofilters in purifying stormwater of $\mathrm{P}$ encourages their implementation in urban catchments, since $\mathrm{P}$ is the main limiting nutrient and $\mathrm{P}$ loading is the primary agent in causing fresh water eutrophication (Wetzel, 2001).

Although biofilter outputs had more dissolved TP and $\mathrm{PO}_{4}$ than stormwater input, concentrations were very low as compared to the high TP in stormwater. In the leaching test, light-expanded aggregates (L) and biochar released 7-11 x more $\mathrm{PO}_{4}$ than the other materials. Vohla et al. (2011) report that L products mostly have high P-sorption capacity, close to $90 \%$, but sometimes $<10 \%$. In other cases, L only had moderate (24\%) P removal (Amado et al., 
2012) or was not reactive to P (Karczmarczyk et al. 2014). In this experiment, amending L with biochar increased $\mathrm{P}$ release, so spruce-based biochar was a source of $\mathrm{P}$, and was also supported by the leaching test. Birch-based biochar is capable of retaining P (Kuoppamäki et al. 2016). Feedstock material and pyrolysis temperature determine the performance of biochar (Shaheen et al., 2018). The same probably applies to clay minerals, the feedstock material of L. Geologic origins of L can be used as a screening criterion for finding potential materials with high P sorption capacity (Baker et al., 2014).

The removal of $\mathrm{P}$ relies on chemical properties of the filter medium, such as the content of $\mathrm{Ca}, \mathrm{Fe}, \mathrm{Al}$ and $\mathrm{Mg}$ (Baker et al., 2014; Shrestha et al., 2018; Vohla et al., 2011). Fil and Con were rich in $\mathrm{Fe}$ and $\mathrm{Al}$, which, together with high $\mathrm{pH}$ probably explain their effective $\mathrm{P}$ retention. However, effluent with very high $\mathrm{pH}(>9)$ may not be allowed to discharge into water bodies, so outlet pH should be neutralized or diluted (Egemose et al., 2012; Vohla et al., 2011), but in Finland high $\mathrm{pH}$ is not of major concern as lakes and rivers are mainly soft and often humic (Niemi et al., 2004).

Biofilters were less effective in the removal of $\mathrm{N}$ than $\mathrm{P}$, the amount of $\mathrm{TN}$ being higher or equal compared to $\mathrm{TN}$ in stormwater, in agreement with previous studies (Blecken et al., 2010; Hatt et al., 2009; Leroy et al. 2016; Shrestha et al,. 2018; Valtanen et al., 2017). $\mathrm{NO}_{\mathrm{x}}$ was well retained by $\mathrm{Lb}$ and $\mathrm{S}$, while the other treatments showed negative retention. Thus, biochar improved $\mathrm{N}$ retention despite elevated $\mathrm{NO}_{\mathrm{x}}$ in the leaching test, perhaps due to the longer detention time in stormwater infiltration compared to that in the leaching test, as increasing detention time can improve retention (Mohanty et al., 2018).

Vegetation had negligible impacts on P retention, in agreement with previous studies by, e.g. Glaister et al. (2014) and Valtanen et al. (2017), although grasses have also been reported to remove TP (Barrett et al., 2013). $\mathrm{N}$ dynamics is driven more by biological 
processes than P dynamics (Shrestha et al., 2018), explaining the generally good $\mathrm{N}$ retention by vegetation in biofiltration (Glaister et al., 2014; Hatt et al., 2009; Henderson et al. 2007; Valtanen et al., 2017). In this experiment, the only significant impact of grasses was the improved $\mathrm{NO}_{\mathrm{x}}$ retention.

\section{Metals}

Metals in stormwater occurred almost exclusively in particulate form, as dissolved forms contributed $c a .<1 \%$ of those in particulate fraction. Especially during cold conditions and snow melt. metals are largely particulate bound in urban runoff (Trowsdale and Simcock, 2011; Valtanen et al., 2014; Westerlund and Viklander, 2006). Biofilters efficiently retained total metals due to the efficient sedimentation and physical straining of suspended solids with the associated metals, in accordance with other biofilter studies (Hatt et al., 2009, Trowsdale and Simcock, 2011). An exception was As that occurred at elevated levels in discharge from L. In the leaching test, As concentration was $2.5 \mathrm{x}$ higher than the maximum limit suitable for tap water in Finland. Arsenic is a natural component of the earth's crust and widely distributed throughout the environment, but being a toxic metalloid can cause groundwater problems (WHO, 2018). As can accumulate in earthworms in high concentrations causing risks to soil ecosystems (Kilpi-Koski et al., 2019). Perhaps clay minerals used in manufacturing L were the source of As. Another trace element present at elevated concentrations was $\mathrm{Cr}$ that leached from Con, although not exceeding maximum limits set for $\mathrm{Cr}$ in Finland.

Dissolved forms of metals were generally much higher in discharge from biofilters compared to those in stormwater input. Flanagan et al. (2019) also found dissolved concentrations of trace metals in outlet water that frequently exceeded those in road runoff 
with much better removal of particle bound metals. Like in the case of $\mathrm{P}$, perhaps also part of the metals bound to particles become dissolved when infiltrating through biofilters.

Vegetation did not affect metal retention, in contrast to previous findings (Feng et al., 2012; Leroy et al., 2016). Despite deep root systems in the L and Lb treatments, discharge contained even higher concentrations of $\mathrm{As}, \mathrm{Cu}$ and $\mathrm{Ni}$ compared to non-vegetated systems, perhaps due to preferential flow paths created by plant roots, as has been found by Feng et al. (2012).

In the real world, the environment always contains mixtures of substances, such as various metals in stormwater entering freshwater systems (EEA, 2018). $\mathrm{Cr}, \mathrm{Cu}, \mathrm{Pb}, \mathrm{Ni}, \mathrm{Zn}$, As, Cd and Co have been listed by the EEA (2018) as metals causing risking the ecological status of water bodies. Water infiltrated through $\mathrm{S}$ had clearly the lowest joint concentrations of substances, indicating the excellence of traditional sand filters over artificial, man-made materials, which were themselves also sources of these elements. However, with the exception of As in L, the concentrations in leachates were well below the limits set for maximum values.

\section{Total organic carbon (TOC)}

Stormwater was rich in TOC, close to maximum values found by Valtanen et al. (2014). Even higher levels were measured in discharge from L, Lb and Con, suggesting these materials as sources of TOC, while Fil and S retained more than half of TOC. TOC carried by stormwater probably stems from organic dust particles, originating from the combustion of fossil fuels (Göbel et al., 2007). Similar to Henderson et al. (2007), this study found negligible impacts of vegetation on the removal of TOC. 


\section{Stormwater infiltration and the fate of MPs}

Vegetation increased stormwater retention in the summer event. Another benefit of plants was the greatly accelerated infiltration, in agreement with previous studies (Barrett et al., 2013; Mangangka et al., 2015; Valtanen et al., 2017). Plant roots create air space, improve water holding capacity and, regardless of season, hydraulic performance (Valtanen et al., 2014). Roots form preferential pathways for water and associated substances, shown for instance by the concentrated presence of MPs along root channels. As MPs were carried by water via these channels, so were obviously also other particles, which - together with associated substances - concentrated along root channels, where MPs were carried deeper in the soil than in non-vegetated systems. No microplastics were detected in discharge, highlighting the efficiency of biofilters in capturing MPs, similar to their capture of TSS. Due to the slow degradation of MPs and, thus, persistence in the environment (Ajith et al., 2020), it is important to develop measures to prevent them from entering water bodies.

\section{Vegetation growth}

$\mathrm{L}, \mathrm{Lb}$ and $\mathrm{S}$ were favorable for the growth of plants, while Fil and Con with very high $\mathrm{pH}$ were detrimental to grasses. Thus, if the latter two filter materials are to be used in vegetated biofilters, they should be neutralized at least to some extent or diluted by mixing with other materials.

\section{CONCLUSIONS}

High amounts of TSS, MPs, TP and total metals in stormwater can be reduced through retention processes in biofilters. Especially important is the removal of $\mathrm{P}$ to prevent eutrophication of adjacent water bodies. Road verges provide feasible sites for biofiltration, 
given the high loading of contaminants from traffic areas. Although none of the materials was identified as ideal for treating both nutrients and metals, traditional sand turned out to be the best filtering material for removing most nutrients and metals, as well as providing a suitable growing medium for vegetation. Of the man-made materials, crushed concrete and Filtralite were more effective in the removal of $\mathrm{P}$ than light-expanded aggregates or biochar. In sites where $\mathrm{P}$ removal is important, Filtralite or concrete aggregates can be considered as alternatives to sand, but high $\mathrm{pH}$ values are unfavorable for plant growth. Thus, man-made materials provide an arena for further studies on how to improve their performance in stormwater treatment solutions. As MPs were detected mostly around plant roots, future studies should unravel whether plant roots can take up MPs $\leq 50 \mathrm{~nm}$, or nanoplastics to be more precise, and the possible ecotoxicological effects of their accumulation in plants. Longer term studies are also needed to determine whether MPs percolate through filter layers in due course. Another important reason for longer term studies spanning for years rather than only weeks is the fact that in due course pollutants will accumulate in biofiltration structures, which was not taken into account in this experiment.

\section{Supplemental information: Appendix A}




\section{ACKNOWLEDGMENTS}

This study, being part of the Hule Smart and Clean project, was funded by the HelsinkiUusimaa Regional Council (project no. AIKO032). AlmaLab (University of Helsinki) and Lammi Biological Station analysed water samples for nutrients and metals as well as conducted the leaching tests. Jeong In Heo, Ji-Hyeon Noh, Amalia Sulk, Laura Tudeer, the students at the University of Helsinki, helped in running the experiment.

\section{REFERENCES}

Ajith, N., Arumugam, S., Parthasarathy, S., Manupoori, S. and Janakiraman, S. 2020. Global distribution of microplastics and its impact on marine environment - a review. Environ. Sci. Pollut. Res. 10.1007/s11356-020-09015-5

Amado, L., Albuquerque and, A., Santo, A.E. 2012. Influence of stormwater infiltration on the treatment capacity of a LECA-based horizontal subsurface flow constructed wetland. Ecol. Eng. 39: 16-23. doi.org/10.1016/j.ecoleng.2011.11.009

Baker, M.D., Simkins, S., Spokas, L.A., Veneman, P.L.M. and Xing, B.S. 2014. Comparison of phosphorus sorption by light-weight aggregates produced in the United States. Pedosphere 24, 808-816. doi.org/10.1016/S1002-0160(14)60068-0

Barrett, M.E., Limouzin, M. and Lawler, D.F. 2013. Effects of plant media and plant selection on biofiltration performance. J. Environ. Eng. 139, 462-470. doi.org/10.1061/(ASCE)EE.1943-7870.0000551

Blecken, G.-T., Zinger, Y., Deletic, A., Fletcher, T.D., Hedström, A. and Viklander; M. 2010. Laboratory study on stormwater biofiltration: Nutrient and sediment removal in cold temperatures. J. Hydrol. 394, 507-514. doi.org/10.1016/j.jhydrol.2010.10.010 
Charters, F.J., Cochrane, T.A., O'Sullivan and A.D. 2016. Untreated runoff quality from roof and road surfaces in a low intensity rainfall climate. Sci. Tot. Env. 550, 265-272. DOI: 10.1016/j.scitotenv.2016.01.093

Eckhart, K., McPhee, Z. and Bolisetti, T. 2017. Performance and implementation of low impact development - A review. Sci. Tot. Env. 607-608, 413-432. doi.org/10.1016/j.scitotenv.2017.06.254

Egemose, S., Sønderup, M.J., Beinthin, M.V., Reitzel, K., Hoffmann, C.C. and Flindt, M.R., 2012. Crushed concrete as a phosphate binding material: A potential new management tool. J. Environ. Qual. 41, 647-653. doi:10.2134/jeq2011.0134

Ellis, J.B. and Mitchell, G. 2006. Urban diffuse pollution: key data information approaches for the Water Framework Directive. Water and Environment Journal 20, 19-26. doi.org/10.1111/j.1747-6593.2006.00025.x

EEA 2018. Chemicals in European waters. European environment Agency, EEA Report No. 18/2018. doi:10.2800/265080

EPA 2011. Marine debris in North Pacific, a summary of existing information and identification of data gaps. Environmental Protection Agency, US EPA-909-R-11006.

Feng, W., Hatt, B.E., McCarthy, D.T., Fletcher, T.D. and Deletic, A. 2012. Biofilters for stormwater harvesting: understanding the treatment performance of key metals that pose a risk for water use. Env. Sci. Technol. 46, 5100-5108. doi.org/10.1021/es203396f

FMI 2020. https://en.ilmatieteenlaitos.fi/climate-elements Finnish Meteorological Institute (accessed 26.11.2020)

Flanagan, K., Branchu, P., Boudahmane, L., Caupos, E. Demare, D., Deshayes, S., Dubois, P., Meffray, L., Partibane, C., Saad, M. and Gromaire, M-C. 2019. Retention and transport 
processes of particulate and dissolved micropollutants in stormwater biofilters treating road runoff. Sci. Tot. Env. 656, 1178-1190. doi.org/10.1016/j.scitotenv.2018.11.304

Funai, J.T. and Kupec, P. 2017. Exploring planting and filter media in stormwater bioremediating landscapes: a review. Water Air Soil Pollut. 228, 340. DOI $10.1007 / \mathrm{s} 11270-017-3524-0$

Glaister, B.J., Fletcher, T.D., Cook, P.L.M. and Hatt, B.E. 2014. Co-optimisation of phosphorus and nitrogen removal in stormwater biofilters: the role of filter media, vegetation and saturated zone. Water Sci. Technol. 69.9 DOI: 10.2166/wst.2014.117

Grimm, N.B., Faeth, S.H., Golubiewski, N.E., Redman, C.L., Wu, J. et al. 2008. Global change and the ecology of cities. Science 319, 756-760. DOI: 10.1126/science.1150195

Göbel, P., Dierkes, C. and Coldwey, W.G. 2007. Storm water runoff concentration matrix for urban areas. J. Contam. Hydrol. 91, 26-42. DOI: 10.1016/j.jconhyd.2006.08.008

Hatt, B.E., Fletcher, T.D. and Deletic, A. 2009. Hydrologic and pollutant removal performance of stormwater biofiltration systems at the field scale. J. Hydrol. 365, 310-321. doi.org/10.1016/j.jhydrol.2008.12.001

Henderson, C., Greenway, M. and Phillips, I. 2007. Removal of dissolved nitrogen, phosphorus and carbon from stormwater by biofiltration mesocosms. Water Sci. Technol. 4, 183-191. 183doi: 10.2166/wst.2007.108

Karczmarczyk, A., Baryła, A. and Bus, A. 2014. Effect of P-Reactive Drainage Aggregates on Green Roof Runoff Quality. Water 6, 2575-2589. DOI: 10.3390/w6092575

Kilpi-Koski, J., Penttinen, O.-P., Väisänen, A.O. and van Gestel, C.A.M. 2019. An uptake and elimination kinetics approach to assess the bioavailability of chromium, copper and arsenic to earthworms (Eisenia andrei) in contaminated field soils. Environmental Science and Pollution Research 26, 15095 - 15104. DOI: 10.1007/s11356-019-04908-6 
Kole, P.J., Löhr, A. J., Van Belleghem, F.G.A.J. and Ragas, A.M.J. 2017. Wear and tear of tyres: a stealthy source of microplastics in the environment. Int. J. Environ. Res. Public Health 14, 1-4. DOI: 10.3390/ijerph14101265

Kuoppamäki, K., Hagner, M., Valtanen, M. and Setälä, H. 2019. Using biochar to purify runoff in road verges of urbanized watersheds: A large-scale field lysimeter study. Wateshed Ecology and the Environment 1, 15-25. doi.org/10.1016/j.wsee.2019.05.001

Kuoppamäki K., Setälä H., Rantalainen A.-H. and Kotze D.J. 2014. Urban snow indicates pollution originating from road traffic. Env. Poll. 195, 56-63. dx.doi.org/10.1016/j.envpol.2014.08.019

Leroy, M.-C., Portet-Koltalo, F., Legras, M., Lederf, F., Moncond'huy, V., Polaert, I. and Marcotte, S. 2016. Performance of vegetated swales for improving road runoff quality in a moderate traffic urban area. Sci. Tot. Environ. 566-567, 113-112. DOI:

10.1016/j.scitotenv.2016.05.027

Mangangka, I., Liu, A., Egodawatta, P. and Goonetilleke, A. 2015. Performance characterisation of a stormwater treatment bioretention basin. J. Env. Manage. 150, 173178. doi.org/10.1016/j.jenvman.2014.11.007

Mohanty, S.K., Valenca, R., Berger, A.W., You, I.K.M., Xiong, X., Sanuders, T.M. and Tsang, D.C.W. 2018. Plenty of room for carbon on the ground: potential applications of biochar for stormwater treatment. Sci. Tot. Env. 625, 1644-1658. DOI:

10.1016/j.scitotenv.2018.01.037

Niemi, J., Lepistö, L., Mannio, J., Mitikka, S. and Pietiläinen, O-P. 2004. Quality and trends of inland waters, pp. 18-40 in: Eloranta, P. (Ed.) Inland and coastal waters of Finland. University of Helsinki, Palmenia publishing. 
Scopetani C., Cincinelli A., Martellini T., Lombardini E., Ciofini A., Fortunati A., Pasquali V., Ciattini S. and Ugolini A. 2018. Ingested microplastic as a two-way transporter for PBDEs in Talitrus saltator. Environ. Res., 167, 411-417. DOI:

10.1016/j.envres.2018.07.030

Shaheen, S.M., Niazi, N.K., Hassan, N.E.E., Bibi, I., Wang, H., Tsang, D.C.W., Ok, Y.S., Bolan and N., Rinklebe, J. 2018. Wood-based biochar for the removal of potentially toxic elements in water and wastewater: a critical review. International Materials Reviews, DOI: $10.1080 / 09506608.2018 .1473096$

Shrestha, P., Hurley, S.E. and Wemple, B.C. 2018. Effects of different soil media, vegetation, and hydrologic treatments on nutrient and sediment removal in roadside bioretention systems. Ecol. Eng. 112, 116-131. doi.org/10.1016/j.ecoleng.2017.12.004

Trowsdale S.A. and Simcock, R. 2011. Urban stormwater treatment using bioretention. J. Hydrol. 397, 167-174. doi.org/10.1016/j.jhydrol.2010.11.023

Valtanen, M., Sillanpää, N. and Setälä, H. 2014. The effects of urbanisation on runoff pollutant concentrations, loadings and their seasonal patterns under cold climate. Water Air Soil Poll. 225, 1977. DOI 10.1007/s11270-014-1977-y

Valtanen, M., Sillanpää, N. and Setälä, H. 2017. A large-scale lysimeter study of stormwater biofiltration under coldclimatic conditions. Ecol. Eng. 100, 89-98. doi.org/10.1016/j.ecoleng.2016.12.018

Vohla, C., Koiv, M., Bavor, H.J., Chazarenc F. and Mander, U. 2011. Filter materials for phosphorus removal from wastewater in treatment wetlands - A review. Ecol. Eng. 37, 7089. DOI: $10.1016 /$ j.ecoleng.2009.08.003 
Westerlund, C. and Viklander, M. 2006. Particles and associated metals in road runoff during snowmelt and rainfall. Sci. Tot. Environ. 362, 143-156.

doi.org/10.1016/j.scitotenv.2005.06.031

WHO 2018. Fact sheet on arsenic in drinking-water. www.who.int/en/news-room/factsheets/detail/arsenic (accessed $16^{\text {th }}$ September 2020)

Wetzel, R.G. 2001. Limnology. Lake and river ecosystems. $3^{\text {rd }}$ edition. Academic Press, NY, USA. 1006 p.

\section{Figure legends:}

Figure 1. Event mean concentrations (averages of the two irrigations) of nutrients in the added stormwater (sw; stars) and in discharge from the five filtration treatments without vegetation (circles) or with vegetation (boxes). The top and bottom of each box are the $3^{\text {rd }}$ and $1^{\text {st }}$ quartiles, respectively. The average is shown with a cross $(\mathrm{x})$ and median with a cross line. Whiskers indicate maximum and minimum values. $\mathrm{L}=$ light-expanded clay aggregates, $\mathrm{Lb}=\mathrm{L}$ amended with biochar, Fil $=$ Filtralite $\mathrm{P}^{\circledR}, \mathrm{Con}=$ crushed concrete and $\mathrm{S}=$ filter sand. 

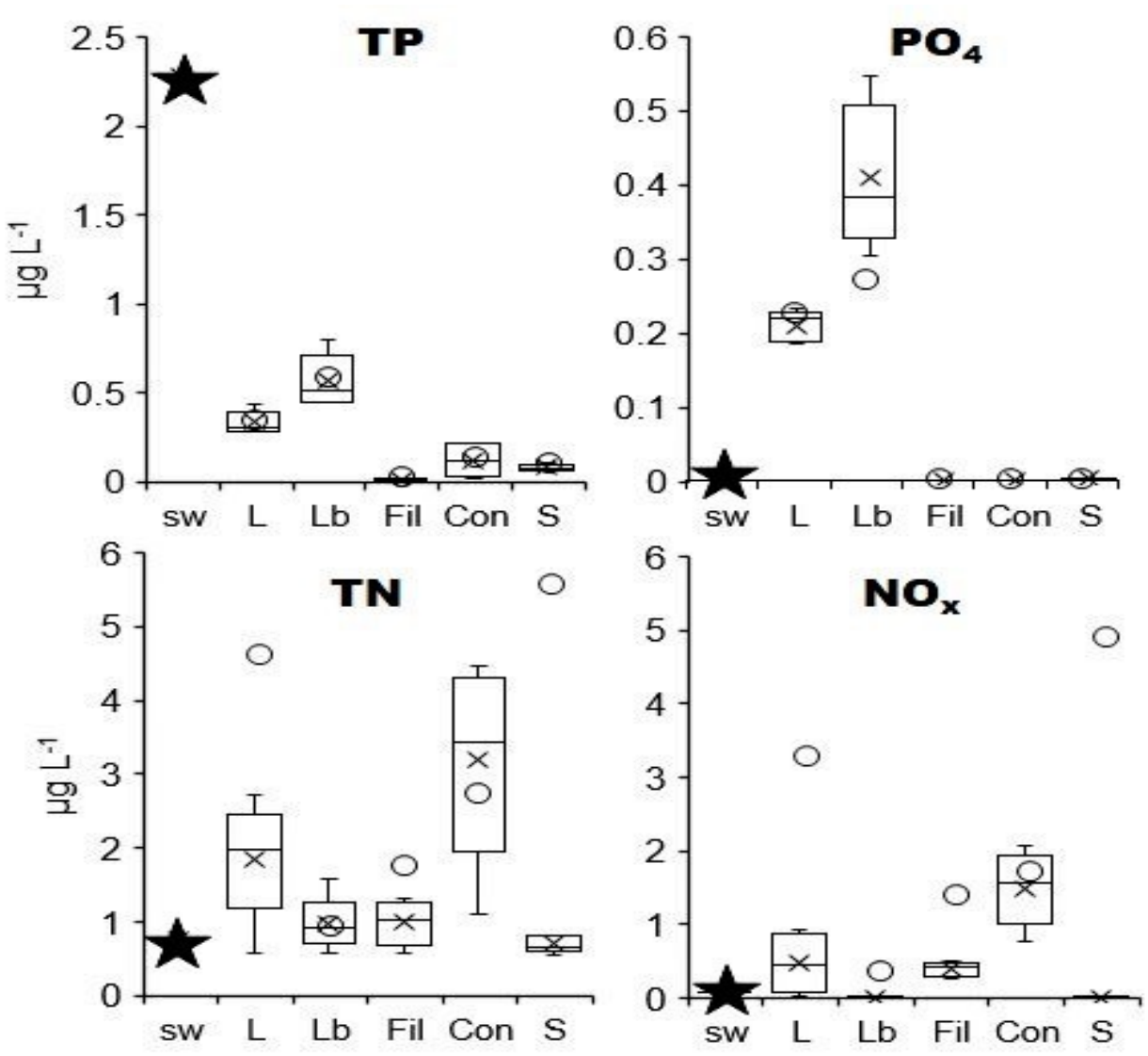

Figure 2. Event mean concentrations (averages of the two irrigations) of dissolved cobalt $(\mathrm{Co})$, cadmium $(\mathrm{Cd})$, arsenic $(\mathrm{As})$, copper $(\mathrm{Cu})$, chromium $(\mathrm{Cr})$, lead $(\mathrm{Pb})$ and nickel $(\mathrm{Ni})$ in the added stormwater (sw; stars) and in discharge from the five filtration treatments without vegetation (circles) or with vegetation (boxes). Also shown is the sum of dissolved metals (final plot) calculated as standardized z-scores from the original concentrations. Treatment abbreviations and box plot details are explained in Fig. 1. 


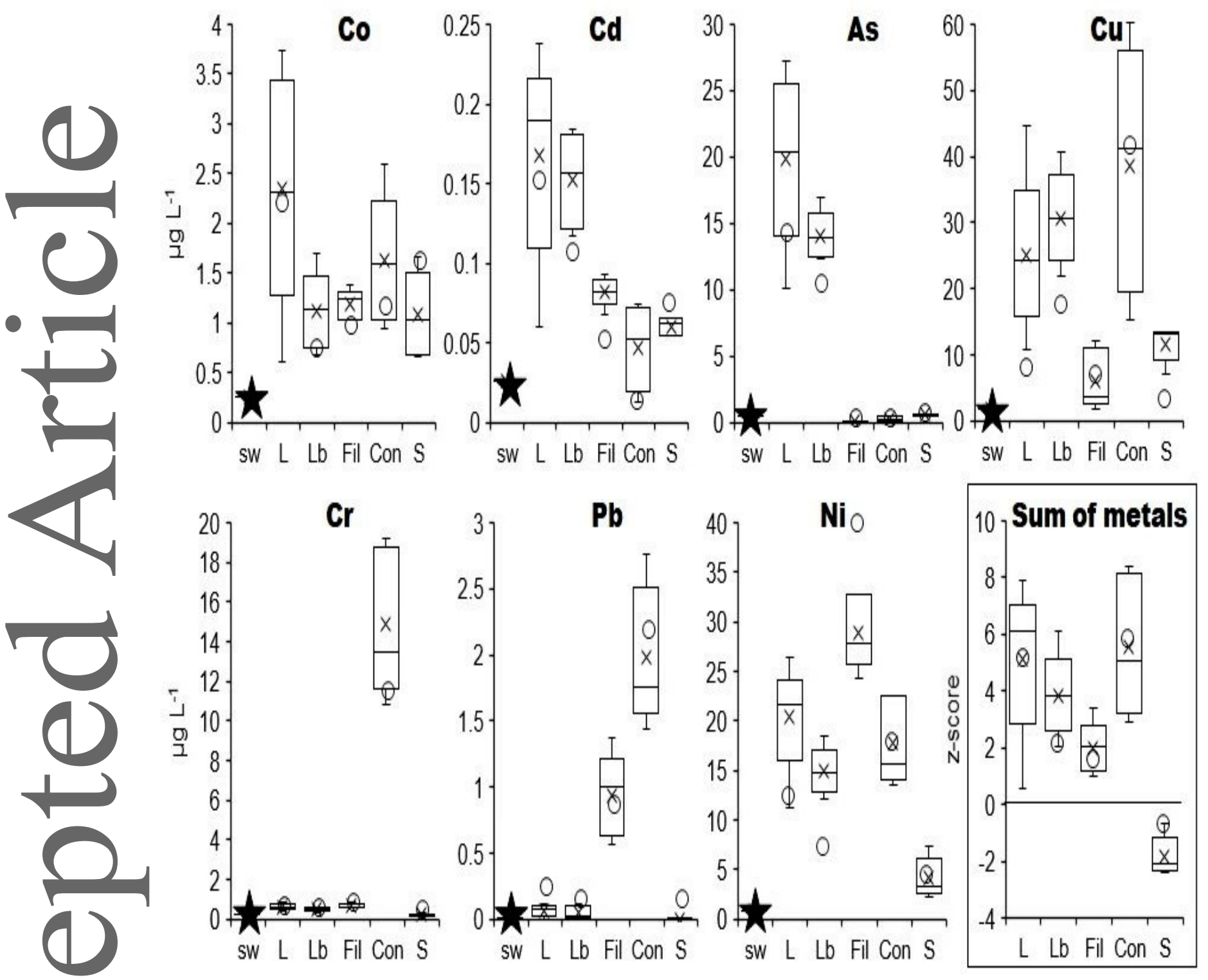

Figure 3. Top $5 \mathrm{~cm}$ of a biofilter structure with the dense root network and associated blue color indicating the presence of microplastics (MPs) in daylight (upper photograph) and the glowing fluorescent blue color of MPs concentrating along root channels in darkness (lower photograph). 


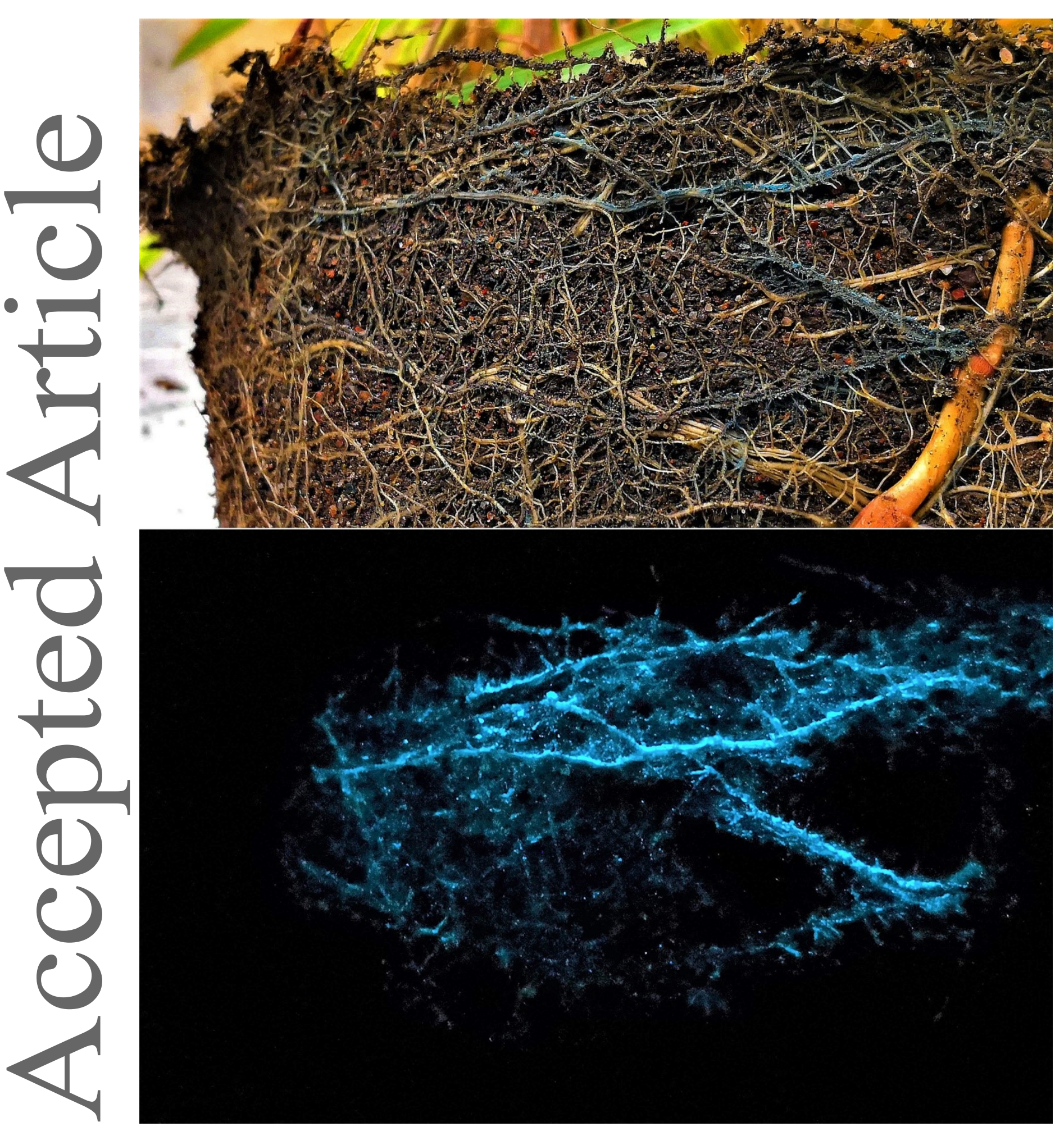

Tables:

This article is protected by copyright. All rights reserved. 
Table 1. The average retention (\%) of nutrients, metals, total suspended solids (TSS), total organic carbon (TOC) and the volumetric retention of stormwater by the vegetated treatments during the two irrigation events simulating spring and summer conditions. Note that the retention of dissolved fractions of both nutrients and metals are computed against concentrations of total (not dissolved) nutrients and metals in stormwater (Figs. 1 and 2 show how much dissolved forms of pollutants in stormwater are retained by biofilters). Lines (-) indicate negative retention, which means that concentrations increased as compared to those in stormwater. Treatment abbreviations are explained in Fig. 1.

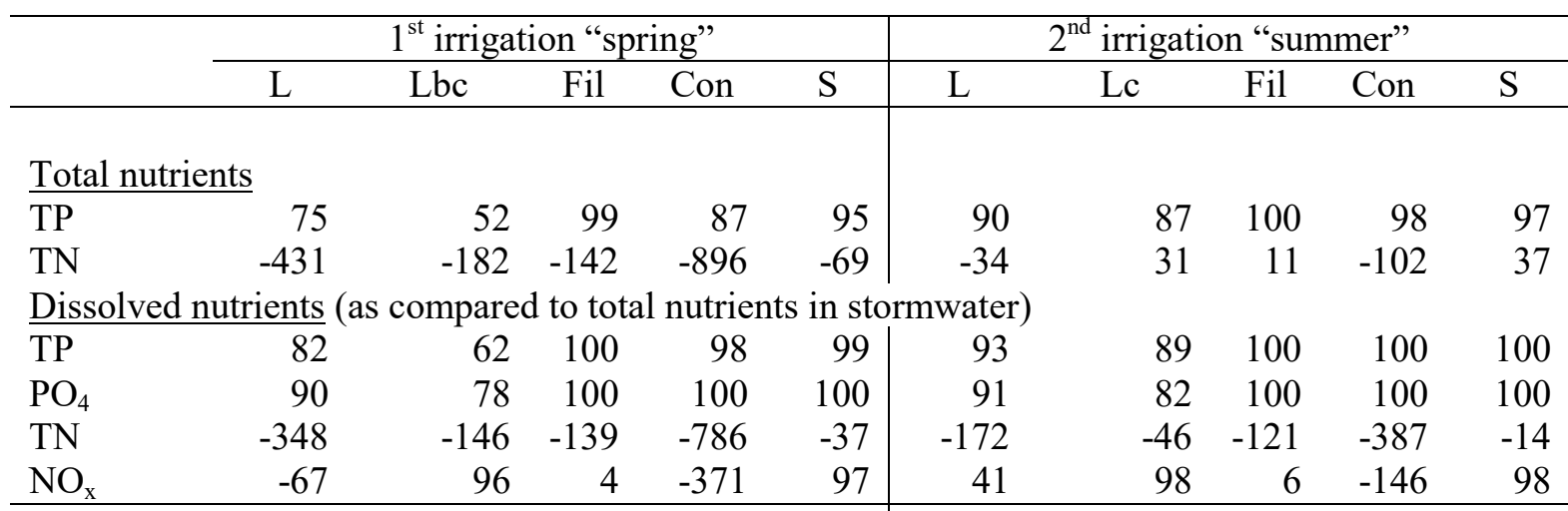

Total metals, i.e. both solid and dissolved

$\begin{array}{lrrrrr}\mathrm{Al} & 100 & 99 & 100 & 99 & 98 \\ \mathrm{Cd} & 78 & 78 & 87 & 89 & 87 \\ \mathrm{Co} & 98 & 98 & 99 & 98 & 97 \\ \mathrm{Cr} & 100 & 99 & 99 & 93 & 98 \\ \mathrm{Cu} & 96 & 93 & 99 & 93 & 95 \\ \mathrm{Ni} & 82 & 84 & 78 & 88 & 92 \\ \mathrm{Zn} & 96 & 98 & 99 & 99 & 97 \\ \mathrm{As} & -95 & -99 & 97 & 93 & 89 \\ \mathrm{~Pb} & 98 & 97 & 95 & 88 & 93\end{array}$

Dissolved metals (as compared to total metals in stormwater)

\begin{tabular}{lrrrrr|rrrrr}
\hline $\mathrm{Al}$ & 100 & 100 & 100 & 100 & 100 & & & & \\
$\mathrm{Cd}$ & 82 & 81 & 92 & 94 & 94 & 84 & 88 & 91 & 96 & 93 \\
$\mathrm{Co}$ & 98 & 99 & 99 & 99 & 99 & 99 & 99 & 99 & 99 & 99 \\
$\mathrm{Cr}$ & 100 & 100 & 100 & 93 & 100 & 100 & 100 & 100 & 95 & 100 \\
$\mathrm{Cu}$ & 96 & 94 & 99 & 94 & 98 & 96 & 97 & 99 & 94 & 98 \\
$\mathrm{Ni}$ & 83 & 85 & 74 & 85 & 95 & 86 & 93 & 82 & 89 & 98 \\
$\mathrm{Zn}$ & 98 & 99 & 100 & 100 & 100 & 100 & 100 & 99 & 100 & 100 \\
$\mathrm{As}$ & -127 & -131 & 97 & 94 & 97 & -75 & -32 & 98 & 96 & 97 \\
$\mathrm{~Pb}$ & 100 & 100 & 99 & 96 & 100 & 100 & 100 & 97 & 95 & 100 \\
\hline TSS & 100 & 96 & 99 & 97 & 98 & 100 & 99 & 99 & 99 & 99 \\
TOC & -9 & -4 & 77 & -123 & 54 & & & & &
\end{tabular}




\begin{tabular}{llllll|llllll} 
volumetric & 28 & 28 & 34 & 36 & 19 & 41 & 36 & 46 & 37 & 39 \\
\hline
\end{tabular}

Table 2. Repeated measures ANOVA results on the effects of irrigation time and biofilters

(treatment) on the event mean concentrations of nutrients, metals, total suspended solids (TSS) and total organic carbon (TOC) as well as $\mathrm{pH}$ in leachate waters collected from vegetated containers following the two stormwater irrigation events. Also shown are differences in the volumetric retention of stormwater. Total metals and TOC were measured only following the first irrigation event. The last column shows the results of a post hoc Tukey's test indicating statistical differences among treatments. Treatment abbreviations and box plot details are explained in Fig. 1.

\begin{tabular}{|c|c|c|c|c|c|c|c|}
\hline & & ne & $\begin{array}{c}\text { Tin } \\
\text { Trea } \\
F \\
\end{array}$ & $\begin{array}{ll}\mathrm{ex} \\
\text { nent }\end{array}$ & $\begin{array}{l}\text { Treat } \\
\quad F\end{array}$ & nent & Tukey's test \\
\hline Nutrients & & & & & & & \\
\hline TP & 3.84 & 0.064 & 0.58 & 0.680 & 47.11 & $<0.001$ & $\mathrm{Lb}>\mathrm{L}>$ Con $>$ Fil $\| \mathrm{Lb}>\mathrm{L}>\mathrm{S}>$ Fil \\
\hline TP dissolved & 6.26 & 0.021 & 1.63 & 0.205 & 11.83 & 0.003 & $\mathrm{Lb}>\mathrm{L}>$ Fil, Con, $\mathrm{S}$ \\
\hline $\mathrm{PO}_{4}$ & 11.85 & 0.003 & 0.86 & 0.502 & 968.14 & $<0.001$ & $\mathrm{Lb}>\mathrm{L}>\mathrm{S}>$ Fil, Con \\
\hline $\mathrm{TN}$ & 11.91 & 0.003 & 2.15 & 0.112 & 4.09 & 0.014 & Con $>\mathrm{S}$ \\
\hline TN dissolved & 29.31 & $<0.001$ & 2.46 & 0.079 & 14.24 & 0.012 & Con $>\mathrm{S}$ \\
\hline $\mathrm{NO}_{\mathrm{x}}$ & 8.81 & 0.008 & 1.82 & 0.165 & 12.97 & $<0.001$ & $\begin{array}{l}\mathrm{L}>\mathrm{Lb}\|\mathrm{L}>\mathrm{S}\| \text { Fil }>\mathrm{Lb} \mid \\
\mathrm{Con}>\mathrm{Lb} \| \text { Fil }>\mathrm{S} \| \mathrm{Con}>\mathrm{S}\end{array}$ \\
\hline Total metals & & & & & & & \\
\hline $\mathrm{Cd}$ & & & & & 2.66 & 0.063 & \\
\hline Co & & & & & 2.57 & 0.070 & \\
\hline $\mathrm{Cr}$ & & & & & 15.16 & $<0.001$ & Con $>$ L, Lb, Fil $\| S>$ Fil \\
\hline $\mathrm{Cu}$ & & & & & 13.47 & $<0.001$ & L, Lb, Con, $\mathrm{S}>$ Fil \\
\hline $\mathrm{Ni}$ & & & & & 6.81 & 0.001 & L, Lb, Fil $>$ S $\|$ Fil $>$ Con \\
\hline $\mathrm{Zn}$ & & & & & 0.72 & 0.585 & \\
\hline As & & & & & 50.54 & $<0.001$ & $\mathrm{~L}, \mathrm{Lb}>$ Fil, Con, $\mathrm{S}$ \\
\hline $\mathrm{Pb}$ & & & & & 15.49 & $<0.001$ & Con $>$ L, Lb $\|$ Fil $>$ L $\| S>L$ \\
\hline Dissolved me & & & & & & & \\
\hline $\mathrm{Cd}$ & 0.20 & 0.66 & 1.17 & 0.352 & 8.87 & 0.001 & $\mathrm{~L}>$ Con, $\mathrm{S} \| \mathrm{Lb}>$ Con \\
\hline Co & 63.22 & $<0.001$ & 1.67 & 0.197 & 1.95 & 0.141 & \\
\hline $\mathrm{Cr}$ & 0.25 & 0.623 & 2.78 & 0.055 & 11.68 & $<0.001$ & Con $>$ L, Lb, Fil, S \\
\hline $\mathrm{Cu}$ & 3.15 & 0.091 & 4.12 & 0.013 & 10.03 & $<0.001$ & L, Lb, Con, $\mathrm{S}>$ Fil \\
\hline $\mathrm{Ni}$ & 69.94 & $<0.001$ & 3.57 & 0.024 & 12.49 & $<0.001$ & $\mathrm{~L}, \mathrm{Lb}$, Fil, Con $>\mathrm{S}$ \\
\hline $\mathrm{Zn}$ & 7.18 & 0.014 & 2.64 & 0.064 & 3.32 & 0.031 & $\mathrm{~L}>\mathrm{Con}$ \\
\hline As & 28.31 & $<0.001$ & 1.04 & 0.412 & 153.03 & $<0.001$ & $\mathrm{~L}, \mathrm{Lb}>$ Fil, Con, $\mathrm{S}$ \\
\hline $\mathrm{Pb}$ & 0.01 & 0.931 & 10.76 & $<0.001$ & 34.16 & $<0.001$ & Fil, Con $>$ L, Lb, S \\
\hline $\mathrm{Ts}$ & 6.27 & 0.021 & 2.43 & 0.081 & 8.19 & $<0.001$ & Lb, Fil, Con, S > L \\
\hline
\end{tabular}


TOC

$\mathrm{pH}$

volumetric
$2.26 \quad 0.148$

$2.98<\mathbf{0 . 0 0 1}$
$13.96 \mathbf{0 . 0 0 3}$ L, Lb, Con $>$ Fil $\|$ Con $>$ S

$26.95<\mathbf{0 . 0 0 1}$ Fil, Con $>$ L, Lb, S

$3.11 \quad \mathbf{0 . 0 3 8} \quad \mathrm{S}>$ Fil

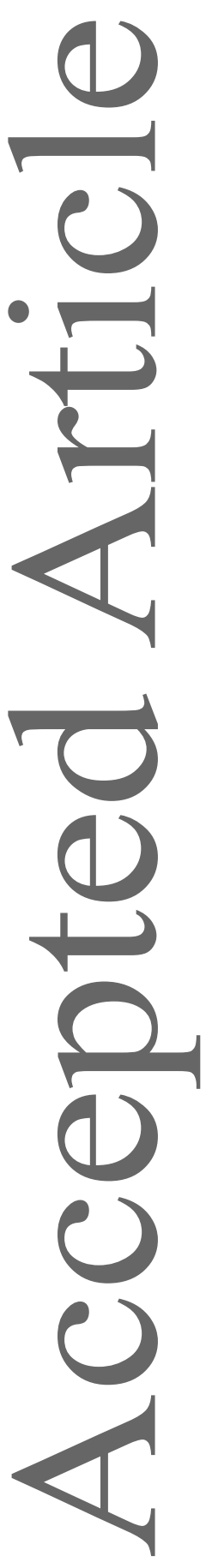

This article is protected by copyright. All rights reserved. 